\title{
An increasing trend of bilateral tubal ectopic gestation reported over the past two decades: a case report and review of literature
}

\author{
Mayuri Ahuja*, Archana Mehta, Neerja Goel, Shehla Jamal
}

Department of Obstetrics and Gynecology, School of Medical Sciences and Research, Greater Noida, Uttar Pradesh, India

Received: 14 April 2018

Accepted: 08 May 2018

*Correspondence:

Dr. Mayuri Ahuja,

E-mail: soniaahuji@redffmail.com

Copyright: (c) the author(s), publisher and licensee Medip Academy. This is an open-access article distributed under the terms of the Creative Commons Attribution Non-Commercial License, which permits unrestricted non-commercial use, distribution, and reproduction in any medium, provided the original work is properly cited.

\begin{abstract}
Bilateral tubal ectopic pregnancies which are spontaneously conceived are of rare occurrences. Generally, they are diagnosed intra-operatively. There are no guidelines published till date for their management. There has been a reported increase in the incidence of such cases. We present a review of such cases reported over the last two decades and report a similar case which presented to our hospital with acute abdomen and USG suggested hemo-peritoneum with further intraoperative diagnosis of bilateral tubal ectopic managed by left salpingectomy and right salpingostomy
\end{abstract}

Keywords: Salpingectomy, Salpingostomy, Ultrasonography

\section{INTRODUCTION}

Bilateral tubal ectopic pregnancies are of rare occurrences and those without prior history of ART or ovulation induction are rarest form of extrauterine pregnancy. Due to their unpredictable clinical presentation and intraoperative diagnosis no definite clinical guidelines have been published till date for their management. The Fish back and Norris diagnostic criteria accepts only histopathological confirmation of chorionic tissue in both tubes. ${ }^{1}$ There has been an increase in reporting of such cases over the past two decades. Authors share their experience with such spontaneously conceived bilateral tubal ectopic pregnancy diagnosed and managed at their hospital and reviewed all the cases reported over the past two decades.

\section{CASE REPORT}

A 29-year-old Gravida 2, Para 1, living issue 1, with previous full term vaginal delivery one year back presented with two months amenorrhea and acute abdomen in the emergency department of SMS \& R. Her urinary pregnancy test was positive. USG suggested massive hemoperitoneum. Her past cycles were regular. No history suggestive of PID, tuberculosis, previous abdominal surgeries done, ovulation induction, infertility treatment in the past or any use of any contraception specially IUCD was elicited. Patient was pale, pulse 110 beats per minute and blood pressure 100 by $60 \mathrm{~mm} \mathrm{Hg}$. Abdomen was distended and there was guarding and rigidity on examination. On per vaginal examination cervical motion tenderness was present, uterine size could not be assessed as all fornices full. With provisional diagnosis of ruptured ectopic pregnancy decision for urgent laparotomy was taken. Two units of packed red blood cells (PRBC) and fresh frozen plasma (FFP) were arranged. Her pre-operative hemoglobin was $5 \mathrm{gm} / \mathrm{dl}$, viral markers (HIV, Hepatitis B Ag, Hepatitis C) were negative, PT (INR)-15(1.3). Patient was shifted to operation theatre for exploration after taking high risk consent. The need of post -operative ICU admission and need of blood transfusion explained. The need of salpingectomy was also explained. Abdomen was opened and approximately 2-2.5 liters of blood was drained. 
There was ruptured ectopic mass of the size of $3 \times 4 \mathrm{~cm}$ on the ampullo-isthmic portion of left tube with active ongoing bleeding from the fimbrial end of the same tube suggestive of tubal abortion. Another $2 \times 3 \mathrm{~cm}$ ectopic mass was present on the ampullary portion of right tube. Family was appropriately counselled. Left salpingectomy and Right salpingostomy was performed. Both the specimen were sent for histopathology which later confirmed chorionic tissue in both the tubes. Peritoneal lavage was done, intra-peritoneal drain was put and abdomen was closed. Patient was given 4 units of PRBC post-operatively. Patient was transferred to ICU on ventilator. Post -operative course was uneventful and she was weaned of the ventilator on the next day. Catheter and drain were removed on day 2. Patient serum beta human chorionic gonadotropin (HCG) was $120 \mathrm{Miu} / \mathrm{ml}$ on the day of operation which reduced to normal levels $<5 \mathrm{~m} \mathrm{IU} / \mathrm{ml}$ after 4 weeks of serial monitoring. Patient was discharged on postoperative day 10 after stitch removal. Hysterosalpingography done 6 months later showed peritoneal spill on right side. Pre-conceptional counselling regarding the risk of repeat ectopic was done patient is under regular follow up.

\section{DISCUSSION}

Many cases of bilateral tubal ectopic go unreported owing to the lack of standardized diagnostic and management protocols for this clinical entity. Causes of bilateral tubal ectopic include multiple ovulation, sequential impregnation, trans peritoneal migration of trophoblastic cells from one tube to the other. ${ }^{2}$ Past history of ovulation induction and ART is significant risk factor for their reported increasing trend. Case reports reported by Mock P et al (2001), Jamilian et al, Saghar et al had past history of ovulation induction/ART. ${ }^{3-5}$ As the diagnosis of ectopic is generally based on empty uterine cavity and unilateral adnexal mass, bilateral adnexal masses are generally missed. Moreover, these cases usually present as ruptured ectopic gestation with gross hemoperitoneum further diminishing their diagnosis on USG. However, USG diagnosis was possible in cases reported by Brown et al and Jamilian et al. ${ }^{4,6}$ Generally, in patients where the serum beta $(\mathrm{HCG})$ is much higher in proportion to the period of gestation and ultrasound is suggestive of ectopic mass the possibility of bilateral tubal ectopic should be kept in mind. Pre-operative diagnosis of this entity might may help in employing the early medical management of such cases. USG diagnosis of this entity might employing the early medical management as done by Mock $\mathrm{P}$ et al. ${ }^{3}$ Laparotomy is done when patient is haemodynamically unstable with gross haemo-peritoneum. But laparoscopy is preferred as there are less chances of adhesion formation which would ultimately lead to decreased rates of repeat ectopic. ${ }^{7}$ Most of the cases reported presented with acute abdomen hence laparotomy was the preferred modality, but laparoscopy was the modality used in the following cases reported. ${ }^{8-13}$ Such case presented earlier and were generally hemodynamic stable at the time of presentation.
Salpingectomy is the management of choice but salpingostomy is offered when family size is not complete with associated risk of persistent and repeat ectopic. Bilateral salpingectomy as means to manage bilateral tubal ectopic were reported in the following cases reported. ${ }^{6,9,14-18}$ Bilateral salpingostomy was performed with the goal of preserving fertility in the following cases reported. ${ }^{10,12,19-20}$ Salpingectomy of one tube and salpingostomy of other tube was performed in the following cases reported., ${ }^{41,13,19,21-26}$ Salpingostomy without suturing carries higher rate of intrauterine pregnancy which may be due to rapid return of tubal function due to minimal injury to the tubal structures. ${ }^{27}$ Viable pregnancy after conservative surgery for bilateral tubal ectopic was reported by Sreeja et al. ${ }^{24}$ Follow up of these patients is extremely important so as to assess the future fertility aspect with this mode of conservative surgery. Re-laparotomy was done where increasing titers of beta (HCG) levels were found after the initial surgery, which on re- exploration showed ectopic mass on the other contralateral side, thus emphasizing the need to examine both tubes, ovaries and peritoneal cavity at the time of surgery to rule out a possibility of simultaneous ectopic pregnancy. ${ }^{24}$ The presenting case presented with acute abdomen and laparotomy was done. Bilateral tubal ectopic was intraoperative diagnosis managed by salpingectomy and salpingostomy. There were no persistent ectopic and the future fertility results are still awaited.

\section{CONCLUSION}

Spontaneously conceived bilateral tubal ectopic are of rare occurrences but there has been an increase in reporting of such cases over the last two decades. Patients of ectopic pregnancy with beta HCG levels much higher in proportion to the gestational age, the possibility of bilateral tubal ectopic should be kept in mind. During USG both adnexa should be carefully examined to rule out the possibility of bilateral tubal ectopic and the similar tale of caution should be employed intraoperatively to exclude their possibility.

\section{ACKNOWLEDGMENTS}

Authors would like to thank Dr Neerja Goel, for her support during study.

\section{Funding: No funding sources \\ Conflict of interest: None declared \\ Ethical approval: Not required}

\section{REFERENCES}

1. Norris S. Bilateral simultaneous tubal pregnancy. Can Med Assosc J.1953;68(4):379-81.

2. Tabachnikoff RM, Dada MO, Woods RJ, Rohere D, Myers CP. Bilateral tubal pregnancy. A report of an unusual case. J of Repr Med. 1998;43(8):707-9. 
3. Mock P, Olivennes F, Doumer S, Frydman R, Fernandez H. Simultaneous bilateral tubal pregnancy after intracytoplasmic injection treated by 1 conservative medical management. Interest of sonography and follow up. Eur J Obstet Gynecol Repr Biol. 2001;94(1):155-7.

4. Jamilian M. Bilateral tubal ectopic pregnancy following intra uterine insemination (IUI): A case report. Iran J Reprod Med. 2014;12(2):155-8.

5. Saghar S, Sedighe H, Nasrin S, Marzeie Z. Bilateral tubal ectopic pregnancies: Case reports of ectopic pregnancy following intrauterine insemination. J Genit Sys Disorder. 2015;4:3.

6. Matthew MI, Brown NE, Onyebuchi AK, Onoh RC, Edegbe FO. Bilateral tubal gestation: a case report. Ann Nig Med. 2014;8(1);45-7.

7. Sepilian V, Wood E. The challenge of ectopic pregnancy. J Nurse Pract. 2006;2:583-592.

8. Andrews J, Farell S. Spontaneous bilateral tubal pregnancy. A case report. J Obstet Gynecol Can. 2008;30:51-4.

9. Martinez J, Ana C, Gonzalez M, Gil O, Farrer M, Romero J. Bilateral Simultaneous Ectopic Pregnancy. Southern Medical Journal 2009;102(10):1055-7

10. Ghaffari F, Poopak Eftekhari Yazdi, Kianicorresponding, K. A case report of bilateral tubal pregnancy following 5 day embryo transfer. Arch Med Sci. 2011;7(6):1087-8.

11. Calagana G, Rossi C, Giorgio A. Maria M, Antonino P, Gaspare C. Spontaneous bilateral tubal pregnancy in a nulliparous woman. Laproscopic diagnosis and treatment. Int J Gynecol Obstet. 2015;27:137-40.

12. Hoffmam S, Abele H, Bachmann C. Spontaneous bilateral tubal pregnancy: Incidental finding during laproscopy- Brief report and review of literature. Geb Fraue. 2016;76(4):413-16.

13. Tariq B, Bruno S, et al. Simultaneous bilateral tubal pregnancy after intracytoplasmic sperm injection and embryo transfer in a patient with stage 3 endometriosis. Gynecol Obstet Case report. 2016;2:3.

14. Shetty JP, Shetty B, MakkanaVar JH. A rare case of bilateral tubal pregnancy. $\mathrm{J}$ of Int Med Assosc. 2011;109(7):5-7.

15. Himangini R, Behra R, Sachdev S. A rare case of bilateral tubal ectopic pregnancy. Pravara Med Rev. 2010;(1):19-21.
16. Prabhleen K, Urvashi M, Kadam VK, Laul P. Concurrent bilateral ectopic pregnancy; a rarity. Int J of Repo Contracept Obstet Gynecol. 2015;4(4):11979.

17. Sheeba M and Supriya G. Spontaneous bilateral tubal gestation: A rare case report. Case Rep Obstset Gynecol. 2016;3-4.

18. Mandal R, Ghosh, S, Mitra S, Basak A, Naskar P, Seth k. et al. Bilateral tubal pregnancy: a diagnostic delimma. Op J Obstet and Gynecol. 2013;3:639-41.

19. Eze J, Obuna J. Spontaneous bilateral tubal pregnancy: a case report of 2 cases. Bilateral tubal ectopic pregnancies. Ann Afr Med. 2012;11(2):1125.

20. Jena SK, Sing S,Nayak M, Das L, Senapati S. Bilateral tubal pregnancy: a case report, review of literature and management algorithm. J Clin Diag Res. 2016;10(3):1-3.

21. Brady J, Wilson M. Spontaneous bilateral tubal ectopic pregnancy. J R Soc Med. 2005;98(3).120-21

22. Quraan G, Taani M, Nusair BM, Masri A, Arfat MR, Khateeb MM. Spontaneously ruptured and intact bilateral tubal ectopic pregnancy. East Med Health J. 2007;13(4):967-72.

23. Marasinghe J, Condous G, Amarasinghe WI. Spontaneous bilateral tubal ectopic pregnancy. Ceylon Med J. 2009. 2009;54(1):21-2.

24. Sreeja R, Geeta P. Viable intrauterine pregnancy after spontaneous bilateral tubal ectopic in a multiparous woman. A case report. J of Med case Rep. 2013;7(1):159.

25. Li W, Wang G, Lin T, Sun W. Misdiagnosis of bilateral tubal pregnancy: a case report. J Med Case Rep. 2014;8:342.

26. Jaghirdar SS, Junghare PS. A rare case of bilateral spontaneous tubal pregnancy. Int $\mathbf{J}$ Rep Obst and Gynecol. 2014;3(4):1116-8.

27. Tulandi T, Guralnick M. Treatment of tubal ectopic pregnancy by salpingostomy with or without tubal suturing and salpingectomy. Fertil Steril. 1991;55(1):53-5.

Cite this article as: Ahuja M, Mehta A, Goel N. An increasing trend of bilateral tubal ectopic gestation reported over the past two decades: a case report and review of literature. Int J Reprod Contracept Obstet Gynecol 2018;7:2518-20. 